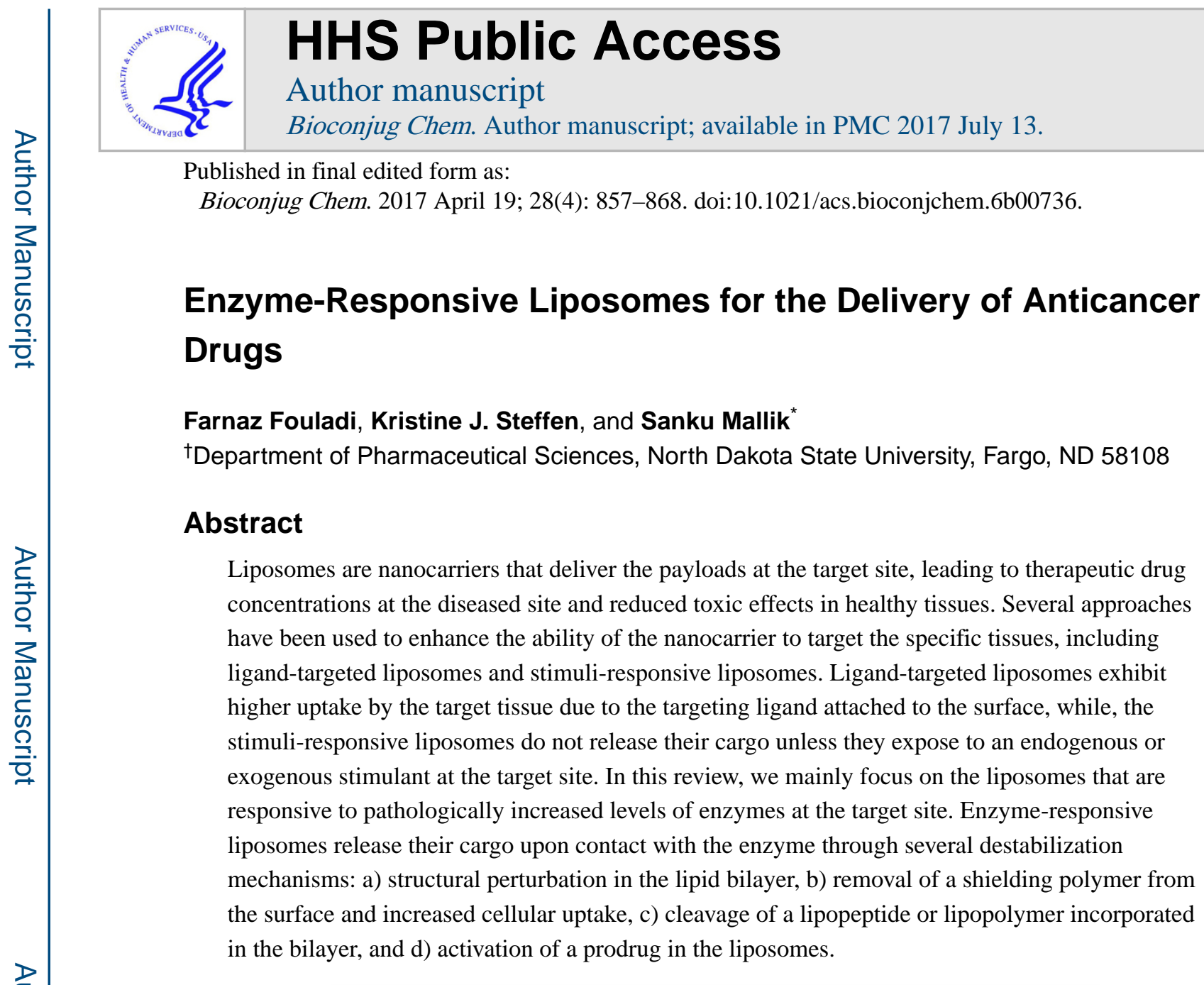

\title{
Introduction
}

Among different nanoparticle-based drug delivery systems such as polymersomes, dendrimers, and magnetic nanoparticles ${ }^{1,2}$, liposomes have gained much popularity in the last few decades, particularly, in cancer therapy. Several characteristics have turned liposomes into suitable in-vivo nanocarriers: the natural phospholipids are biodegradable, biocompatible, nontoxic, and weakly immunogenic ${ }^{3}$. Liposomes encapsulate a broad range of drugs, and release the payloads at a target site, resulting in therapeutic drug concentration at the diseased site and reduced toxic effects in healthy tissues ${ }^{4}$. In addition, liposomes increase bioavailability and reduce clearance of drugs by increasing circulation and residence time in the body ${ }^{5}$. In this review, we discuss different types of enzyme-responsive liposomes which can enhance drug delivery in cancer treatment.

\section{Structure of Liposomes}

Liposomes are self-assembled vesicles with single or multiple phospholipid bilayers. Due to the amphiphilic nature of the constituent phospholipids, the liposomes can carry both hydrophilic and lipophilic drugs ${ }^{6}$. The hydrophilic drugs are encapsulated in the aqueous

\footnotetext{
"Corresponding author's address: Department of Pharmaceutical Sciences, College of Health Professions, 1401 Albrecht Boulevard, Fargo, ND 58108. Sanku.Mallik@ndsu.edu, Tel: 701-231-7888, Fax: 701-231-8333.
} 
core or conjugated to the membrane surface. Hydrophobic drugs are incorporated into the lipid bilayer of the vesicles ${ }^{5}$. A schematic illustration of a liposome and two common phospholipids used in the formulation of liposomes are shown in Figure 1.

Liposomes are composed of natural or synthetic phospholipids. The lipid composition of liposomes has a significant impact on their stability, physicochemical, and pharmacokinetic properties. Depending on the type of phospholipids, liposomes may be cationic, anionic, or neutral at the physiological $\mathrm{pH}^{5}$. For example, liposomes composed of dialkyl phosphatidylcholine or phosphatidylethanolamine are neutral, while vesicles made of phosphatidylserine and phosphatidylglycerol have a net negative charge ${ }^{5}$ (Figure 2). The surface charge has a significant effect on the stability of liposomes both in the formulation and serum. Incorporation of other lipophilic compounds such as cholesterol into the bilayer decreases the fluidity of membrane and reduces premature drug leakage ${ }^{7}$.

\section{In-vivo Stability of Liposomes}

Unilamellar liposomes are generally between $50-250 \mathrm{~nm}$ in diameter ${ }^{3}$, and able to deliver their cargo to the targeted tissues. However, the classical liposomes have a very short blood circulation time due to serum protein opsonization and uptake by the reticular endothelium system $^{8}$. One common approach to increase the circulation half-life of liposomes is to attach polyethylene glycol (PEG) on the surface (PEGylation), introduced by Klibanov et al., ${ }^{9}$ and further developed by several other researchers ${ }^{10-14}$. The grafted hydrophilic polyethylene glycol on the surface of liposomes offers steric hindrance and prevents the adsorption of opsonins and subsequent endocytosis by the phagocytes. Moreover, steric repulsion induced by surface PEG layer prevents liposome aggregation and increases stability. Therefore, these sterically stabilized liposomes, termed as stealth liposomes, have a prolonged blood circulation time ${ }^{3}$. The half-life of circulation for liposomes with PEG with the molecular weight range $1900-5000$ is increased to $9-16$ hours $^{15}$. Doxil ${ }^{\circledR}$, introduced in 1995 , is the first FDA-approved PEGylated liposome for the treatment of ovarian cancer, Kaposi's sarcoma, and breast cancer ${ }^{16}$.

\section{Passive Targeting vs. Active Targeting}

\section{Passive targeting of liposomes}

Liposomes passively accumulate in the target tissues through penetration retention effect ${ }^{17,18}$. Vasculatures in tissues affected by the tumor, infection, and inflammation have higher permeability and larger pores relative to the vasculatures in healthy tissues. Thus, drug-loaded liposomes in the range $60-150 \mathrm{~nm}$ extravasate from the vasculatures into the diseased tissues, and subsequently release their cargo at the desirable site of action ${ }^{19}$. In addition, the retention of liposomes is enhanced in the tumor tissues due to poor lymphatic drainage ${ }^{20}$. These properties have made drug-loaded liposomes superior to free drugs which unselectively distribute into both healthy and diseased tissues. Upon arrival of liposomes at the target site, drug releases through passive diffusion across the bilayer lipid. Released drug diffuses in the interstitial fluid of the target tissue and is subsequently up-taken by the target cells ${ }^{19}$. 


\section{Ligand-targeted Liposomes}

In passive targeting, the liposomes can enter normal tissues and release their drug in the vicinity of healthy cells, resulting in off-target toxic effects. This problem is alleviated by conjugating targeting ligands on the surface of liposomes. The ligand can be an antibody, peptide, glycoprotein, carbohydrate, or a ligand which recognizes and binds to a specific antigen or receptor overexpressed (or selectively expressed) on the diseased cells. If the ligand stimulates receptor-mediated internalization, target cells uptake the liposomes via endocytosis and the loaded drug is released inside the cell ${ }^{19}$. The receptor-mediated endocytosis of the ligand-targeted liposomes has important implications for the intracellular delivery of therapeutic agents such as macromolecules ${ }^{21}$.

The targeted liposomes are associated with better therapeutic outcomes of anti-cancer drugs in animal tumor models compared to non-targeted vesicles ${ }^{22,23}$. However, some reports also suggest that the targeted liposomes are not more effective in vivo compared to non-targeted counterparts $^{24}$. Premature leakage of the encapsulated drugs, lack of internalization, low density of antigens on the target cells, and low permeability to the target tissues may decrease the effects of targeting ${ }^{21}$. Due to the high cost of development, no ligand-targeted liposomes have reached the market yet. However, a few phase I and II clinical trials are in progress involving transferrin-targeted oxaliplatin liposomes (MBP-426) and glutathionecoated, doxorubicin liposomes (2B3-101) .

\section{Stimuli-responsive Liposomes}

The targeted liposomes, upon reaching the intended sites, release the encapsulated drugs through passive diffusion, and this process is often slow. A strategy to enhance the release rate of the encapsulated drugs is to design environmentally-responsive liposomes. These liposomes do not release their cargo until an endogenous or exogenous stimulus induces structural changes in liposomes. A rapid release of the encapsulated drug ensures its therapeutic concentration at the target site and reduces the possibility of developing drug resistance. Endogenous stimuli are pathological changes in the target cancer tissues, such as reduced $\mathrm{pH}^{25}$, overexpression of specific enzymes, and abundance of reducing agents ${ }^{4}$. Lack of these triggers in healthy tissues prevents the release of drugs from liposomes, and therefore, protects healthy cells from toxic effects of anti-cancer drugs. In addition, liposomes can be rendered responsive to exogenous or remote triggers such as heat ${ }^{26}$, light ${ }^{27}$, ultrasound ${ }^{28}$, and magnetic field ${ }^{29}$. The targeting ability of the stimuli-responsive liposomes can be enhanced by incorporation of suitable ligands into liposomes ${ }^{30}$.

In this review, we mainly focus on enzyme-responsive liposomes and specifically their applications in drug delivery. Enzyme-responsive liposomes offer several advantages over other stimuli-responsive vesicles. The drug release is triggered by an enzyme that exists in the targeted tissue, and therefore, the liposomes do not need an external equipment to trigger the drug release. This can be beneficial in a clinical setting ${ }^{31}$. Localized release of the encapsulated drug reduces the side effects. In addition, enzyme-responsive liposomes can be designed to produce bioactive molecules following enzyme digestion. These molecules may exhibit synergistic therapeutic effects or facilitate the uptake of the drug at the target tissue $^{32}$. Furthermore, the amount of drug release from enzyme responsive liposomes is 
proportional to the concentration of the active enzyme and the severity of the pathological condition at the target site.

\section{Enzyme-Responsive Liposomes}

In several pathological conditions, such as inflammation, infection, and cancer, the concentrations of several enzymes are elevated. This biochemical abnormality can be used as the trigger to design nanocarriers which undergo structural transformation leading to the release of the encapsulated payload. This strategy has been used to develop enzymeresponsive nanoparticles from polymers, gold, quantum dots, and liposomes ${ }^{32}$. In the following sections of this review, we summarize the enzyme-responsive liposomal formulations that are triggered by different extracellular and intracellular enzymes.

\section{Extracellular Enzymes}

\section{Secreted Phospholipase A2}

Secreted phospholipase A2 ( $\left.\mathrm{SPLA}_{2}\right)$ increases in various inflammatory diseases, atherosclerosis, and cancers. It has also been shown that $\mathrm{SPLA}_{2}$ is increased in the prostate, breast, and pancreatic cancers ${ }^{33-41}$. Therefore, $\mathrm{SPLA}_{2}$ responsive liposomes can be a promising carrier for the targeted delivery of anticancer agents to the tumor tissues. Particularly, $\mathrm{sPLA}_{2}$ responsive liposomes are promising for prostate cancer since $\mathrm{SPLA}_{2}$ IIA increases up to 22 fold in high-grade and metastatic prostate tumors ${ }^{34,42,43}$. One example of $\mathrm{SPLA}_{2}$ responsive liposomes for the treatment of prostate cancer was reported by Mock et al. Doxorubicin-loaded $\mathrm{SLA}_{2}$ responsive liposomes were prepared with 1,2-distearyl-snglycero-3-phosphocholine (DSPC), 1,2-distearyl-sn-glycero-3-phosphoethanolamine (DSPE), cholesterol, and DSPE-PEG 2000 . The liposomes were approximately 2.5 times more effective in reducing tumor growth in a mouse model of human prostate cancer compared with conventional sterically stabilized liposomes, containing DSPC, cholesterol, and DSPE-PEG 2000 .

The $\mathrm{SPLA}_{2}$ is also increased in infections due to the secretion of the enzyme by several bacteria $^{45}$. Antibiotics-loaded sPLA 2 -responsive liposomes offer several advantages over conventional liposomes in the treatment of infections: they release high concentrations of antibiotics at the site of infection where bacteria secrete $\mathrm{SPLA}_{2}$, and the amount of drug release from liposomes is regulated by the concentration of the enzyme at the target site. Therefore, more amount of drug is released from liposomes in more severe infection (which is associated with higher concentrations of $\mathrm{sPLA}_{2}$ ). A recent example of such liposomes has been demonstrated by Thamphiwatana et al. Doxycycline loaded liposomes, stabilized by chitosan-modified gold nanoparticles (AuChi), showed approximately six times more antibacterial effect against Helicobacter Pylori in vitro compared to empty AuChi liposomes. The antibacterial effect was decreased when a PLA2 inhibitor was added to the cell culture, suggesting that the release of doxycycline was dependent on the sPLA ${ }_{2}$ activity 46 .

sPLA 2 Mechanism of Action- sPLA $_{2}$ is a $\mathrm{Ca}^{2+}$-dependent esterase ${ }^{47}$. It hydrolyzes phospholipids at the $s n 2$-fatty acyl ester position, producing free fatty acid and lysophospholipid ${ }^{48,49}$. sPLA $_{2}$-mediated hydrolysis of the phospholipids incorporated into 
liposomes disrupts the integrity of the lipid bilayer and releases the encapsulated payloads (Figure 3). The different isoforms of sPLA ${ }_{2}$ display altered substrate selectivity and hydrolytic activity. For example, Zhu et al. have shown that $\mathrm{SPLA}_{2}$ group III is more potent in degrading liposomes than $\mathrm{SPLA}_{2}$ IIa in vitro ${ }^{50}$. Also, incorporation of cholesterol into PEG-free liposomes had a different effect on the contents release depending on the type of sPLA $_{2}$ isoform. The addition of cholesterol in the liposome bilayer had an inhibitory effect on the contents release by $\mathrm{SPLA}_{2}$ group III compared to $\mathrm{SPLA}_{2} \mathrm{IIa}^{50}$. The $\mathrm{sPLA}_{2}$ IIa isoform is active specifically toward anionic lipid membranes, while other sPLA2 isoforms (such as those derived from snake venom, mammalian $\mathrm{PLA}_{2} \mathrm{~V}$ and $\mathrm{X}$ groups) hydrolyze both anionic and zwitterionic lipid membranes ${ }^{48,51}$.

sPLA $_{2}$ has higher hydrolytic activity toward aggregated forms of lipids, such as bilayers and micelles compared to lipid monomers ${ }^{52}$. Physical properties and composition of the aggregated lipids have a substantial impact on the activity of $\mathrm{sPLA}_{2}{ }^{53-56}$. For example, the liposomes made from phospholipids with short acyl chains and anionic polar head groups are more susceptible to hydrolysis ${ }^{44}, 50$. Particularly, phosphatidylethanolamine and phosphatidylglycerol are the most susceptible to hydrolysis by $\mathrm{SPLA}_{2}{ }^{50}$. Zhu et al. have also demonstrated that incorporation of DSPE or distearoylphosphatidylglycerol (DSPG) into liposomes (containing DSPC, cholesterol, and DSPE- $\mathrm{PEG}_{2000}$ ) increased the release of encapsulated content in the presence of FBS $10 \%(\mathrm{v} / \mathrm{v})$ and $\mathrm{sPLA}_{2}$ to approximately 1.4 and 1.6 times more, respectively, compared to the vesicles lacking DSPE and DSPG over 108 $\mathrm{h}^{50}$. The addition of an $\mathrm{SPLA}_{2}$ inhibitor to this media decreased the release from liposomes containing DSPE or DSPG to the extent similar to the control liposomes without $\mathrm{SPLA}_{2}$. These results confirm that the release from these liposomes is mediated by $\mathrm{SLA}_{2}{ }^{44}$. Apart from the lipid components, grafted PEG on the surface of liposomes increases the hydrolytic activity of $\mathrm{SPLA}_{2}{ }^{50,57-60}$. Incorporation of DSPE-PEG increased the degradation and subsequent release of 6-carboxyfluorescein from liposomes independent of the enzyme isoform and incorporated phospholipids ${ }^{50}$. It has been suggested that the presence of lipopolymer (lipid-PEG) changes the microscopic lateral organization of the lipid bilayer, resulting in increased enzymatic activity of SPLA2 ${ }^{57}$.

In addition to disruption of the lipid bilayer and subsequent release of the drug, other mechanisms have been proposed to regulate drug uptake from $\mathrm{SLA}_{2}$ responsive liposomes. Quach et al. have suggested that phospholipase $A_{2}$ receptor (PLA2R1) might play a role in the uptake of $\mathrm{sPLA}_{2}$ responsive liposomes ${ }^{61}$. PLA2R1 is a transmembrane glycoprotein and responsible for internalization of $\mathrm{SPLA}_{2}$ which ultimately results in the degradation of the enzyme. PLA2R1 also regulates various biological functions, such as cell proliferation, cell migration, lipid metabolism, and cytokine production ${ }^{62}$. In addition, it has been recently shown that PLA2R1 might act as a tumor suppressant ${ }^{63}$. Knockdown of PLA2R1 in prostate cancer cells led to increased uptake of sPLA $_{2}$ responsive liposomes compared to sterically stabilized liposomes. Although the mechanism is not yet clear, one possible explanation is that PLA2R1 has a regulatory effect on $\mathrm{SPLA}_{2}$. This was substantiated by the observation that inhibition of PLA2R1 increased the expression of sPLA 2 group IIA which was associated with increased drug and liposome uptake ${ }^{61}$. Whether PLA2R1 has a direct effect on the uptake of $\mathrm{SLA}_{2}$ responsive liposomes has not yet been established. 
Another factor that affects drug uptake from sPLA 2 responsive liposomes is the products of phospholipid hydrolysis, including lysophospholipids and free fatty acids. These products synergistically enhance the permeability of cell membranes ${ }^{59,64}$, leading to increased cellular uptake of the drugs. The hydrolysis products enhance permeability by integrating into lipid membranes and causing defects (by lateral phase separation) or inducing a curvature stress in the membrane ${ }^{59}$. Interestingly, the accumulation of the hydrolysis products in the lipid bilayer and subsequent changes in the morphology of the membrane further increases $\mathrm{SPLA}_{2}$ activity ${ }^{65}$.

$\mathbf{s P L A}_{\mathbf{2}}$ Sensitive Lipoid Prodrug-The acyl chain at $s n-2$ position in a phospholipid (or ether phospholipid) can be replaced with a lipophilic drug, cleavable by sPLA 2 . These lipoid prodrugs form liposomes and accumulate at the target site, where a high concentration of $\mathrm{sPLA}_{2}$ liberates the active drug from the liposomes. These liposomes are more stable and have overcome some problems associated with conventional liposomes, including limited efficiency of lipophilic drug encapsulation and release ${ }^{66,67}$. Such liposomal prodrugs have been prepared for some drugs, such as chlorambucil ${ }^{68}$, prostaglandine ${ }^{69}$, and retinoic acid ${ }^{70}$ (Figure 4).

One example of liposomal prodrugs was developed by Arouri and Mourtisen ${ }^{66}$. They prepared liposomes which contained 1-O-Stearyl-2-RAR-C6-sn-glycero-3-phosphoglycerol as a C6-RAR prodrug (Figure 4A) and 1,2-dipalmitoyl-sn-glycero-3-phosphocholine (DPPC). RAR, 4-(4-octylphenyl)-benzoic acid, is a selective antagonist for the retinoic acid receptor $\beta 2^{71,72}$ and inhibits cell growth ${ }^{70}$. In the lack of sPLA 2 , C6-RAR prodrug had $\mathrm{IC}_{50}$ of $110 \mu \mathrm{M}$ in the MT-3 breast carcinoma cell line. However, upon addition of $\mathrm{sLA}_{2}, \mathrm{IC}_{50}$ decreased to $10 \mu \mathrm{M}$, indicating that the prodrug was hydrolyzed to C6-RAR and Lyso-OSPG (both are toxic with $\mathrm{IC}_{50}$ of approximately $20 \mu \mathrm{M}$ in the cell cultures without $\left.\mathrm{sPLA}_{2}\right)^{66}$. In addition, premixing of prodrug and DPPC had an additive effect on the $\mathrm{IC}_{50}$ of the mixture in the presence of $\mathrm{SPLA}_{2}$. DPPC also accelerated the hydrolysis rate of the prodrug, probably due to increased heterogeneity of the membrane ${ }^{66}$. Although the in-vivo study of the effectiveness of these liposomes was not demonstrated, such lipoid prodrug can be a very promising delivery model for toxic lipophilic drugs.

Interestingly, liposomes themselves can act as prodrugs if they release cytotoxic lysolipids, including antitumor ether lipids (AELs) under enzymatic digestion. In this approach, liposomes are prepared from proAELs (which are phospholipids with one non-hydrolyzable ether bond at $s n-1$ position and are hydrolyzed to AELs by sPLA 2 , Figure 5). AELs exhibit cytotoxicity and inhibit cell growth ${ }^{73,74}$. However, the toxicity of AELs is limited to the target site since a high concentration of $\mathrm{SLLA}_{2}$ (enough for degradation of liposomes) is found only in the tumor site. It has also been demonstrated that proAEL liposomes lacked hemolytic effect and systemic toxicity compared to a potent AEL $\left(\mathrm{ET}-18-\mathrm{OCH}_{3}\right)$ in vivo and vitro $^{75,76}$.

Overall, liposomes are good carriers for targeted delivery of lipid-based prodrugs to tumor sites. Prodrugs are converted into active drug at the tumor site by $\mathrm{SLA}_{2}$. Such delivery systems protect healthy tissues against the toxic effects of the drug. 


\section{Matrix Metalloproteinases}

Matrix metalloproteinases (MMPs) are $\mathrm{Zn}^{2+}$ and $\mathrm{Ca}^{2+}$ dependent proteolytic enzymes responsible for the degradation of extracellular matrix ${ }^{77}$. Beyond their physiological functions such as angiogenesis, wound healing, and tissue remodeling, these enzymes are overexpressed in several inflammatory diseases, cardiovascular diseases, and cancers ${ }^{78}$. MMPs play important roles in growth, invasion, and metastasis of tumors ${ }^{79-81}$. Particularly, MMP-2 and MMP-9 are found in breast ${ }^{82}$, colorectal $^{83}$, pancreatic ${ }^{84}$, and lung tumors ${ }^{85}$.

Several MMP-sensitive peptides have been designed and incorporated into liposome formulations. These peptides act as linkers between the lipids and the polymer. The polymer prevents the uptake of liposomes through a shielding effect. Upon contact with MMPs at the target site, the peptide is cleaved, leading to the detachment of the polymer and subsequent uptake of liposomes. One example of such MMP-responsive liposomes was reported by Zhu et al. ${ }^{86}$ containing two types of lipopolymers: mAb 2C5-PEG(3400)-MMP2 cleavable peptide-1,2-dioleoyl-sn-glycero-3-phosphoethanolamine (DOPE) and TATp-PEG(2000)-1,2dioctadecanoyl-sn-glycero-3-phosphoethanolamine (DSPE; Figure 6). The former lipopolymer, with a longer chain of PEG, functions as a protective shield over the latter lipopolymer containing the TAT peptide. TAT enhances the endocytosis-mediated uptake of the liposomes. The mAb 2C5 is a targeting moiety for cancer cells. Cleavage of the peptide (Gly-Pro-Leu-Gly-Ile-Ala-Gly-Gln) at the target site liberates the long-chain PEG and removes its shielding effect. The hydrolysis leads to the exposure of TAT peptide and increased uptake of liposomes ${ }^{86}$.

Liposomes containing a galactosylated cholesterol derivative have also been prepared for delivery of chemotherapeutics to the hepatocellular carcinoma (HCC $)^{87}$. These liposomes are taken up by the cancer cells upon binding of galactose to the asialoglycoprotein receptors. To target the liposomes to the hepatocellular tumor, PEG was attached to the phospholipid DOPE via an MMP-2 cleavable peptide linker (Figure 7). The PEG group shields the galactose ligand on the surface of liposomes and prevents their cellular uptake. However, the elevated MMP-2 concentration in HCC cleaves the linker, leading to the release of PEG. Subsequently, the exposed galactose ligand binds to the asialoglycoprotein receptor on the surface of HCC cells ${ }^{87}$. Terada et al. have shown that the uptake of Gal-PEGDOPE $(0.5 \%)$ liposomes were significantly enhanced in the presence of more than $5 \mu \mathrm{g} / \mathrm{mL}$ hMMP-2 in HepG2 cells ${ }^{87}$. The liposomes were also stable in the serum for more than 24 hours ${ }^{87}$.

Another strategy to prepare MMP-responsive liposomes is the incorporation of MMPcleavable lipopeptides into the lipid bilayer. Elevated MMP concentration at the target site cleaves the lipopeptide, leading to destabilization of the membrane and leakage of the liposomal contents. It has been demonstrated that lipopeptides with the sequence StearoylGPQGIAGQR(GPO) ${ }_{4} \mathrm{GG}$ form collagen-mimetic triple helices on the surface of liposomes ${ }^{88-91}$. The triple helical structure makes the peptide a good substrate for collagenase MMPs while imparting resistance to cleavage by noncollagenase MMPs (MMP-7 and MMP-10) and other proteolytic enzymes. MMP can cleave between the amino acids glycine and isoleucine ${ }^{89}$. Liposomes containing $30 \%$ of such lipopeptide and $70 \%$ of 
1-palmitoyl-2-oleoyl-sn-glycero-3-phosphocholine released their contents in the presence of MMP-9 in a concentration and time-dependent manner ${ }^{88,89}$. In these formulations, the type of phospholipid also affects the release of liposomal contents. Incorporation of phospholipids containing acyl chains mismatched with the acyl chain of lipopeptide results in more contents release. Lipid mismatching causes greater demixing of phospholipids and lipopeptide, ${ }^{88,91}$ and reduces the ability of the membrane to recover quickly when defects are formed by the cleavage of triple helices ${ }^{88}$.

\section{Urokinase Plasminogen Activator}

The concentration of urokinase plasminogen activator (uPA), a serine protease, is elevated in a number of human cancers, such as breast, colon, bladder, and ovarian tumors ${ }^{92}$. The uPA contributes to angiogenesis, tumor progression, and metastasis ${ }^{93}$. The enzyme cleaves the Arg-Ser bond in peptides containing the consensus sequence Ser-Gly-Arg-Ser-Ala ${ }^{92}$. Therefore, liposomes containing such uPA-cleavable peptide can release their encapsulated payload upon contact with uPA at tumor sites.

Basel et al. developed uPA responsive liposomes in a hyperosmotic medium, stabilized with a copolymer cage on the surface ${ }^{94}$. The copolymer contained the uPA cleavable peptide and poly (acrylic acid) anchored to cholesterol. After incorporation into liposomes, the copolymer was cross-linked with ethylenediamine. This crosslinked copolymer cage conferred osmotic pressure resistance to the unstable liposomes containing the hyperosmotic contents. Upon incubation with uPA in a medium of physiological osmolarity, the copolymer degraded, and the osmotic swelling of liposomes released their contents. The lipid bilayer composition and cross-linking of copolymer affected the elasticity and water permeation of the liposomes. ${ }^{94}$.

\section{Elastase}

Elastase is a protease secreted from azurophil granules of activated neutrophils and is involved in inflammatory diseases ${ }^{95}$ such as arthritis ${ }^{96}$, acute lung injury ${ }^{97}$, cystic fibrosis, ${ }^{98}$ and tumors ${ }^{99}$ of lungs ${ }^{100}$, breast ${ }^{101}$, and skin $^{102}$. Elastase-sensitive fusogenic liposomes were first developed by Pak et al ${ }^{103}$ from DOPE conjugated to N-acetyl-Ala-Ala via an amide linkage (N-Ac-AA-DOPE is an elastase substrate). Conjugation of Ala-Ala with DOPE changed the shape of the phospholipid from inverted cone to cylindrical form, leading to the formation of bilayer vesicles. Cleavage of the dipeptide by elastase at the target site restored the fusogenic property of DOPE which led to the destabilization and fusion of the liposomes. The liposomes also contained 1,2-dioleoyl-3-trimethylammoniumpropane (DOTAP) to confer positive charges to liposomes after the cleavage of the anionic AA-DOPE. Positively charged liposomes have the greater fusogenic capability with negatively charged cell membranes. Pak et al. have shown that pretreatment of DOTAP/NAc-AA-DOPE/PE liposomes with active proteinase $\mathrm{K}$ (which has a similar substrate specificity to elastase) simulated lipid mixing and fusion with either the target liposomes or cells (RBC ghosts) in vitro ${ }^{103}$. The same research group developed a similar liposomal model from the more sensitive and selective elastase substrate N-methoxy-succinyl-Ala-AlaPro-Val-DOPE ${ }^{104}$. Replacement of DOTAP with 1,2-dioleoyl-3-dimethylammonium- 
propane (DODAP) conferred positive charges to the liposomes at lower $\mathrm{pH}$ following enzymatic cleavage and increased the fusogenicity. These liposomes enhanced the intracellular delivery of water soluble encapsulated contents at $\mathrm{pH} 5$ when pretreated with elastase. These results suggest that elastase triggerable fusogenic liposomes can be useful for the cytoplasmic delivery of drugs ${ }^{104}$.

\section{Prostate-Specific Antigen (PSA)}

Prostate-specific antigen (PSA) is a serine protease found in high concentrations in the prostate tumor tissues ${ }^{105}$. PSA is also present in the serum of prostate cancer patients but is enzymatically inactivated ${ }^{105,106}$. Thus, PSA positive extracellular matrix of prostate tissue is a suitable trigger for the release of anticancer agents. A number of PSA-activated prodrugs have been developed from PSA-cleavable peptides with very selective antitumor activity in vitro and in vivo ${ }^{107-110}$.

Xiang et al. prepared siRNA loaded liposomes containing a peptide (ACPP) with three domains ${ }^{111}$ : the cell penetrating polyarginine $\left(\mathrm{GR}_{8} \mathrm{GC}\right)^{112}$, the PSA-cleavable HSSKYQ, and the polyanionic DGGDGGDGGDGG. In this peptide, the polyanionic domain interacts with polyarginine via electrostatic interaction and shields its cell-penetrating effect. The high concentration of PSA at the target site cleaved the peptide, resulting in the detachment of polyanionic domain and subsequent activation of the cell penetrating peptide (CPP, Figure 8). The cationic polyarginine peptide also promoted endosomal escape and enhanced the cytoplasmic delivery of liposomes. The targeting of these liposomes was further enhanced by attaching the folate moiety on the surface. Folate binds to the prostate-specific membrane antigen (PSMA), a glycoprotein transporter upregulated in prostate cancer cells ${ }^{113}$. In the presence of PSA, the uptake of the liposomes containing both ACPP and folate was highest (in vitro) compared to the control vesicles with one or no ligand ${ }^{111}$. Furthermore, the presence of both folate ligand and the PSA-responsive peptide significantly enhanced the RNA-mediated gene silencing and growth inhibition of the cancer cells. In vivo studies showed selective and prolonged accumulation of the dual-functionalized liposomes in mice prostate tumors (subcutaneously 22Rv1 xenograft). The liposomes reduced the tumor growth significantly ${ }^{111}$. This system is very promising for highly specific delivery of therapeutic agents to prostate cancer.

\section{Intracellular Enzymes}

\section{Cathepsin B}

Cathepsin B, a lysosomal protease of the papain family, is overexpressed in several pathological conditions and malignancies, including the brain, breast, colon, prostate, and lung cancers ${ }^{114}$. The enzyme enhances extracellular matrix degradation through interaction with cystatins and annexin II tetramer. Cathepsin B also affects the activity of other proteases such as MMPs, uPA, and plasmin ${ }^{114}$.

Increased levels of cathepsin B have been exploited to activate liposomal fusogenicity at the target sites. These liposomes were composed of DOPE, a fusogenic non-bilayer forming phospholipid. At the physiologic $\mathrm{pH}$, DOPE adopts an inverted hexagonal $\mathrm{H}_{\mathrm{II}}$ phase ${ }^{115}$. 
However, incorporation of a polymer-lipid conjugate stabilizes the structure of liposomes containing DOPE in a lamellar phase. In Romberg's study, the fusogenic liposomes were stabilized by poly hydroxyethyl L-glutamine (PHEG) anchored to the N-succinyldioctadecyl amine (DODASuc-PHEG, Figure 9) ${ }^{116}$. The incorporation of PHEG prolonged the blood circulation half-life of the liposomes in rats ${ }^{117}$. PHEG is degradable by the proteases cathepsin B, pronase, and papain. Therefore, the authors hypothesized that at the high concentrations of these enzymes at the target site would cleave the peptides, leading to structural change, destabilization, and fusion of liposomes. In the in-vitro study, the presence of $36 \mu \mathrm{g}$ pronase $\mathrm{E} / \mu \mathrm{mol}$ total lipid led to complete release of the liposomal contents following 24 hours. The release from control liposomes containing DOPE/PEG-DSPE was not different by pronase $\mathrm{E}^{116}$. The results indicate that shedding of the polymer from the surface is necessary for the destabilization of the liposomes and release of the contents. It would also be interesting to investigate the contents release from these liposomes in the presence of cathepsin B.

Since cathepsin B is mainly found in the acidic environment of lysosomes, liposomes responsive to both acidic $\mathrm{pH}$ and cathepsin $\mathrm{B}$ have been developed for targeted intracellular delivery of therapeutic agents. In this approach, $\mathrm{pH}$-sensitive liposomes are prepared from unsaturated phosphatidylethanolamines, such as DOPE (non-bilayer forming lipid) and a stabilizer, such as oleic acid, cholesterol hemisuccinate, and palmitoyl homocysteine ${ }^{118}$. The stabilizers are acidic amphiphiles, negatively charged at physiological $\mathrm{pH}$. Therefore, due to electrostatic repulsion, liposomes can form a stable bilayer structure at physiological $\mathrm{pH}$. However, at lower $\mathrm{pH}$, the carboxylate moieties of these stabilizers are protonated. The neutralization of the negative change reverses liposomes from lamellar phase to hexagonal phase and releases the entrapped contents ${ }^{119,120}$. To increase the plasma stability of $\mathrm{pH}$ sensitive liposomes containing DOPE/cholesterol hemisuccinate, Zhang et al. incorporated $15 \mathrm{~mol} \%$ of $\mathrm{mPEG}_{2000}$-DSPE in the bilayer ${ }^{121}$. The mPEG-lipid conjugate further stabilized the lamellar phase and reduced the $\mathrm{pH}$-sensitivity of the liposomes ${ }^{122,}{ }^{123}$. Therefore, Zhang et al. developed formulations in which mPEG was attached to DSPE either via a disulfide bond or cathepsin B-cleavable peptide. It was hypothesized that the cleavage of mPEG groups would restore the $\mathrm{pH}$ sensitivity of liposomes. However, in their study, the release rates were not significantly different between liposomes with cleavable and non-cleavable mPEG at pH 5.5 in the presence of cathepsin B and dithiothreitol. This might be due to the remaining lipid anchor (modified DSPE) which inhibited hexagonal $\mathrm{H}_{\mathrm{II}}$ transition and release of entrapped doxorubicin ${ }^{121}$. Moreover, insufficient cleavage of PEG might have inhibited the release of the encapsulated drug from PEG cleavable liposomes in acidic $\mathrm{pH}$.

\section{Conclusions}

Liposomes are nanocarriers with a lot of potential to deliver therapeutic agents to the diseased sites. In the last few decades, several liposomal drugs have been marketed and are commercially available ${ }^{5}$. Several strategies have been employed to enhance the targetability of liposomal formulations. For the environmental stimuli-responsive liposomes, the release of the payload is triggered by a stimulus at the target site. Enzyme-responsive liposomes release their cargo upon exposure to an upregulated enzyme in the targeted tissue. The most 
common examples of upregulated enzymes in cancerous or inflammatory tissues are sPLA 2 and proteases, such as cathepsin B.

Different strategies have been developed for liposomal contents release in the presence of enzymes. Usually, a biocatalytic reaction at the membrane surface induces perturbation and disrupts the integrity of the lipid bilayer. The structural perturbation releases the encapsulated cargo at the diseased site. In another strategy, liposomes are stabilized by a polymer coating, degradable by a specific enzyme at the target site. Enzymatic cleavage of the polymer destabilizes liposomes and releases the encapsulated contents. Enzymeresponsive liposomes may also carry a ligand that further enhances targeted delivery. Liposomal prodrugs are also of considerable interest for enzyme responsive delivery. In this approach, liposomes contain drug molecules chemically conjugated to the lipids of the bilayer. The active drug is released from liposomes after the linker is cleaved by an enzyme in the target site. This strategy offers advantages for delivery of highly toxic lipophilic drugs that show low loading efficiency by conventional encapsulation methods.

Although enzyme responsive liposomes have been successfully developed and tested in vitro, the translation into clinical studies is lacking. The complex design, sophisticated pharmaceutical development, and difficulties in scale-up make the translation of enzyme responsive liposomes from bench to bedside challenging. In addition, the efficacy of enzyme responsive liposomes, similar to other endogenous stimuli-responsive nanocarriers, may be different from one patient to another due to different levels of the trigger at the target tissue $^{124}$. Therefore, future studies need to address the applicability and effectiveness of these novel formulations in chemotherapy.

\section{Acknowledgments}

FF was supported by the Department of Pharmaceutical Sciences, North Dakota State University. SM acknowledges the support front the grants NSF DMR 1306154, and NIH 1 R01GM 114080.

\section{Abbreviations}

$\begin{array}{ll}\text { PEG } & \text { polyethylene glycol } \\ \text { SPLA2 } & \text { Secreted phospholipase A2 } \\ \text { DSPC } & \text { 1,2-distearyl-sn-glycero-3-phosphocholine } \\ \text { DSPE } & \text { 1,2-distearyl-sn-glycero-3-phosphoethanolamine } \\ \text { DSPG } & \text { distearoylphosphatidylglycerol } \\ \text { PLA2R1 } & \text { phospholipase A } 2 \text { receptor } \\ \text { DPPC } & \text { 1,2-dipalmitoyl-sn-glycero-3-phosphocholine } \\ \text { AELs } & \text { ether lipids } \\ \text { MMPs } & \text { Matrix metalloproteinases } \\ \text { DOPE } & \text { 1,2-dioleoyl-sn-glycero-3-phosphoethanolamine }\end{array}$




$\begin{array}{ll}\text { HCC } & \text { hepatocellular carcinoma } \\ \text { UPA } & \text { urokinase plasminogen activator } \\ \text { PHEG } & \text { poly hydroxyethyl L-glutamine } \\ \text { DODAP } & \text { 1,2-dioleoyl-3-dimethylammonium-propane } \\ \text { DOTAP } & \text { 1,2-dioleoyl-3-trimethylammonium-propane } \\ \text { PSA } & \text { Prostate-specific antigen } \\ \text { CPP } & \text { cell penetrating peptide } \\ \text { PSMA } & \text { prostate specific membrane antigen }\end{array}$

\section{References}

1. Kumari P, Ghosh B, Biswas S. J Drug Target. 2016; 24:179-191. [PubMed: 26061298]

2. Anajafi T, Mallik S. Therapeutic delivery. 2015; 6:521-534. [PubMed: 25996048]

3. Immordino ML, Dosio F, Cattel L. Int J Nanomedicine. 2006; 1:297-315. [PubMed: 17717971]

4. Deshpande PP, Biswas S, Torchilin VP. Nanomedicine (London, England). 2013; 8doi: 10.2217/ nnm.2213.2118

5. Kraft JC, Freeling JP, Wang Z, Ho RJ. J Pharm Sci. 2014; 103:29-52. [PubMed: 24338748]

6. Mallick S, Choi JS. J Nanosci Nanotechnol. 2014; 14:755-765. [PubMed: 24730295]

7. Allen TM, Cleland LG. Biochim Biophys Acta. 1980; 597:418-426. [PubMed: 7370258]

8. Ishida T, Harashima H, Kiwada H. Biosci Rep. 2002; 22:197-224. [PubMed: 12428901]

9. Klibanov AL, Maruyama K, Torchilin VP, Huang L. FEBS Lett. 1990; 268:235-237. [PubMed: 2384160]

10. Blume G, Cevc G. Biochim Biophys Acta. 1990; 1029:91-97. [PubMed: 2223816]

11. Allen TM, Hansen C, Martin F, Redemann C, Yau-Young A. Biochim Biophys Acta. 1991; 1066:29-36. [PubMed: 2065067]

12. Maruyama K, Yuda T, Okamoto A, Ishikura C, Kojima S, Iwatsuru M. Chem Pharm Bull (Tokyo). 1991; 39:1620-1622. [PubMed: 1934187]

13. Senior J, Delgado C, Fisher D, Tilcock C, Gregoriadis G. Biochim Biophys Acta. 1991; 1062:7782. [PubMed: 1998713]

14. Papahadjopoulos D, Allen TM, Gabizon A, Mayhew E, Matthay K, Huang SK, Lee KD, Woodle MC, Lasic DD, Redemann C. Proceedings of the National Academy of Sciences. 1991; 88:1146011464.

15. Allen TM. Advanced Drug Delivery Reviews. 1994; 13:285-309.

16. Barenholz Y. Journal of Controlled Release. 2012; 160:117-134. [PubMed: 22484195]

17. Fang J, Nakamura H, Maeda H. Adv Drug Deliv Rev. 2011; 63:136-151. [PubMed: 20441782]

18. Torchilin V. Adv Drug Deliv Rev. 2011; 63:131-135. [PubMed: 20304019]

19. Sapra P, Allen TM. Prog Lipid Res. 2003; 42:439-462. [PubMed: 12814645]

20. Greish, K. J Drug Target. Vol. 15. England: 2007. p. 457-464.

21. Allen TM, Cullis PR. Adv Drug Deliv Rev. 2013; 65:36-48. [PubMed: 23036225]

22. Lopes de Menezes DE, Pilarski LM, Allen TM. Cancer Res. 1998; 58:3320-3330. [PubMed: 9699662]

23. Park JW, Hong K, Kirpotin DB, Colbern G, Shalaby R, Baselga J, Shao Y, Nielsen UB, Marks JD, Moore D, Papahadjopoulos D, Benz CC. Clin Cancer Res. 2002; 8:1172-1181.

24. Vingerhoeds MH, Steerenberg PA, Hendriks JJ, Dekker LC, Van Hoesel QG, Crommelin DJ, Storm G. Br J Cancer. 1996; 74:1023-1029. [PubMed: 8855969] 
25. Karanth H, Murthy RS. J Pharm Pharmacol. 2007; 59:469-483. [PubMed: 17430630]

26. Needham D, Anyarambhatla G, Kong G, Dewhirst MW. Cancer Res. 2000; 60:1197-1201. [PubMed: 10728674]

27. Wan, Y., Angleson, JK., Kutateladze, AG. J Am Chem Soc. Vol. 124. United States: 2002. p. 5610-5611.

28. Schroeder A, Honen R, Turjeman K, Gabizon A, Kost J, Barenholz Y. Journal of Controlled Release. 2009; 137:63-68. [PubMed: 19303426]

29. Zhu L, Huo Z, Wang L, Tong X, Xiao Y, Ni K. International Journal of Pharmaceutics. 2009; 370:136-143. [PubMed: 19114095]

30. Bibi S, Lattmann E, Mohammed AR, Perrie Y. J Microencapsul. 2012; 29:262-276. [PubMed: 22208705]

31. Movahedi F, Hu RG, Becker DL, Xu C. Nanomedicine: Nanotechnology, Biology and Medicine. 2015; 11:1575-1584.

32. de la Rica R, Aili D, Stevens MM. Advanced Drug Delivery Reviews. 2012; 64:967-978. [PubMed: 22266127]

33. Dennis EA, Cao J, Hsu YH, Magrioti V, Kokotos G. Chemical reviews. 2011; 111:6130-6185. [PubMed: 21910409]

34. Graff JR, Konicek BW, Deddens JA, Chedid M, Hurst BM, Colligan B, Neubauer BL, Carter HW, Carter JH. Clin Cancer Res. 2001; 7:3857-3861. [PubMed: 11751475]

35. Pruzanski W, Vadas P. J Rheumatol. 1988; 15:1601-1603. [PubMed: 3070027]

36. Rosengren B, Jonsson-Rylander AC, Peilot H, Camejo G, Hurt-Camejo E. Biochim Biophys Acta. 2006; 1761:1301-1308. [PubMed: 17070102]

37. Leistad L, Feuerherm AJ, Ostensen M, Faxvaag A, Johansen B. Clin Chem Lab Med. 2004; 42:602-610. [PubMed: 15259375]

38. Yamashita S, Yamashita J, Ogawa M. Br J Cancer. 1994; 69:1166-1170. [PubMed: 8198986]

39. Kiyohara H, Egami H, Kako H, Shibata Y, Murata K, Ohshima S, Sei K, Suko S, Kurano R, Ogawa M. Int J Pancreatol. 1993; 13:49-57. [PubMed: 8384235]

40. Dong, Q., Patel, M., Scott, KF., Graham, GG., Russell, PJ., Sved, P. Cancer Lett. Vol. 240. Ireland: 2006. p. 9-16.

41. Yamashita S, Yamashita J, Sakamoto K, Inada K, Nakashima Y, Murata K, Saishoji T, Nomura K, Ogawa M. Cancer. 1993; 71:3058-3064. [PubMed: 8490834]

42. Jiang J, Neubauer BL, Graff JR, Chedid M, Thomas JE, Roehm NW, Zhang S, Eckert GJ, Koch MO, Eble JN, Cheng L. The American Journal of Pathology. 2002; 160:667-671. [PubMed: 11839587]

43. Sved, P., Scott, KF., McLeod, D., King, NJ., Singh, J., Tsatralis, T., Nikolov, B., Boulas, J., Nallan, L., Gelb, MH., Sajinovic, M., Graham, GG., Russell, PJ., Dong, Q. Cancer Res. Vol. 64. United States: 2004. p. 6934-6940.

44. Mock JN, Costyn LJ, Wilding SL, Arnold RD, Cummings BS. Integr Biol (Camb). 2013; 5:172182. [PubMed: 22890797]

45. Sitkiewicz I, Stockbauer KE, Musser JM. Trends Microbiol. 2007; 15:63-69. [PubMed: 17194592]

46. Thamphiwatana S, Gao W, Pornpattananangkul D, Zhang Q, Fu V, Li J, Obonyo M, Zhang L. J Mater Chem B Mater Biol Med. 2014; 2:8201-8207. [PubMed: 25544886]

47. Cummings BS, McHowat J, Schnellmann RG. J Pharmacol Exp Ther. 2000; 294:793-799. [PubMed: 10945826]

48. Lambeau G, Gelb MH. Annu Rev Biochem. 2008; 77:495-520. [PubMed: 18405237]

49. Six, DA., Dennis, EA. Biochim Biophys Acta. Vol. 1488. Netherlands: 2000. p. 1-19.

50. Zhu G, Mock JN, Aljuffali I, Cummings BS, Arnold RD. Journal of pharmaceutical sciences. 2011; 100:3146-3159. [PubMed: 21455978]

51. Leidy, C., Linderoth, L., Andresen, TL., Mouritsen, OG., Jorgensen, K., Peters, GH. Biophys J. Vol. 90. United States: 2006. p. 3165-3175.

52. Jorgensen, K., Davidsen, J., Mouritsen, OG. FEBS Lett. Vol. 531. Netherlands: 2002. p. 23-27.

53. Halperin A, Mouritsen OG. Eur Biophys J. 2005; 34:967-971. [PubMed: 15883844] 
54. Honger, T., Jorgensen, K., Biltonen, RL., Mouritsen, OG. Biochemistry. Vol. 35. United States: 1996. p. 9003-9006.

55. Hoyrup P, Callisen TH, Jensen MO, Halperin A, Mouritsen OG. Physical Chemistry Chemical Physics. 2004; 6:1608-1615.

56. Honger, T., Jorgensen, K., Stokes, D., Biltonen, RL., Mouritsen, OG. Methods Enzymol. Vol. 286. United States: 1997. p. 168-190.

57. Vermehren, C., Kiebler, T., Hylander, I., Callisen, TH., Jorgensen, K. Biochim Biophys Acta. Vol. 1373. Netherlands: 1998. p. 27-36.

58. Jorgensen K, Vermehren C, Mouritsen OG. Pharm Res. 1999; 16:1491-1493. [PubMed: 10496671]

59. Davidsen J, Jørgensen K, Andresen TL, Mouritsen OG. Biochimica et Biophysica Acta (BBA) Biomembranes. 2003; 1609:95-101. [PubMed: 12507763]

60. Davidsen J, Vermehren C, Frokjaer S, Mouritsen OG, Jørgensen K. International Journal of Pharmaceutics. 2001; 214:67-69. [PubMed: 11282239]

61. Quach ND, Mock JN, Scholpa NE, Eggert MW, Payre C, Lambeau G, Arnold RD, Cummings BS. Mol Pharm. 2014; 11:3443-3451. [PubMed: 25189995]

62. Hanasaki, K. Biol Pharm Bull. Vol. 27. Japan: 2004. p. 1165-1167.

63. Bernard D, Vindrieux D. Biochim Biophys Acta. 2014; 1846:40-44. [PubMed: 24667060]

64. Davidsen, J., Mouritsen, OG., Jorgensen, K. Biochim Biophys Acta. Vol. 1564. Netherlands: 2002. p. 256-262.

65. Mouritsen, OG., Andresen, TL., Halperin, A., Hansen, PL., Jakobsen, AF., Jensen, UB., Jensen, MO., Jorgensen, K., Kaasgaard, T., Leidy, C., Simonsen, AC., Peters, GH., Weiss, M. J Phys Condens Matter. Vol. 18. England: 2006. p. S1293-1304.

66. Arouri, A., Mouritsen, OG. Eur J Pharm Sci. Vol. 45. Elsevier BV; Netherlands: 2012. p. 408-420.2011

67. Arouri A, Mouritsen OG. J Liposome Res. 2011; 21:296-305. [PubMed: 21438721]

68. Pedersen PJ, Christensen MS, Ruysschaert T, Linderoth L, Andresen TL, Melander F, Mouritsen OG, Madsen R, Clausen MH. J Med Chem. 2009; 52:3408-3415. [PubMed: 19402667]

69. Pedersen, PJ., Adolph, SK., Andresen, TL., Madsen, MW., Madsen, R., Clausen, MH. Bioorg Med Chem Lett. Vol. 20. Elsevier Ltd; England: 2010. p. 4456-4458.2010

70. Pedersen PJ, Adolph SK, Subramanian AK, Arouri A, Andresen TL, Mouritsen OG, Madsen R, Madsen MW, Peters GH, Clausen MH. J Med Chem. 2010; 53:3782-3792. [PubMed: 20405849]

71. Lund BW, Piu F, Gauthier NK, Eeg A, Currier E, Sherbukhin V, Brann MR, Hacksell U, Olsson R. J Med Chem. 2005; 48:7517-7519. [PubMed: 16302793]

72. Lund BW, Knapp AE, Piu F, Gauthier NK, Begtrup M, Hacksell U, Olsson R. J Med Chem. 2009; 52:1540-1545. [PubMed: 19239230]

73. Berkovic, D. Gen Pharmacol. Vol. 31. England: 1998. p. 511-517.

74. Andresen TL, Jensen SS, Madsen R, Jorgensen K. J Med Chem. 2005; 48:7305-7314. [PubMed: 16279790]

75. Jensen, SS., Andresen, TL., Davidsen, J., Hoyrup, P., Shnyder, SD., Bibby, MC., Gill, JH., Jorgensen, K. Mol Cancer Ther. Vol. 3. United States: 2004. p. 1451-1458.

76. Andresen TL, Davidsen J, Begtrup M, Mouritsen OG, Jorgensen K. J Med Chem. 2004; 47:16941703. [PubMed: 15027860]

77. Verma, RP., Hansch, C. Bioorg Med Chem. Vol. 15. England: 2007. p. 2223-2268.

78. Yan C, Boyd DD. J Cell Physiol. 2007; 211:19-26. [PubMed: 17167774]

79. Stetler-Stevenson WG, Aznavoorian S, Liotta LA. Annu Rev Cell Biol. 1993; 9:541-573. [PubMed: 8280471]

80. Chambers AF, Matrisian LM. J Natl Cancer Inst. 1997; 89:1260-1270. [PubMed: 9293916]

81. Curran, S., Murray, GI. J Pathol. Vol. 189. John Wiley \& Sons, Ltd; England: 1999. p. 300-308.1999

82. La Rocca, G., Pucci-Minafra, I., Marrazzo, A., Taormina, P., Minafra, S. Br J Cancer. Vol. 90. England: 2004. p. 1414-1421. 
83. Mook, OR., Frederiks, WM., Van Noorden, CJ. Biochim Biophys Acta. Vol. 1705. Netherlands: 2004. p. 69-89.

84. Keleg S, Büchler P, Ludwig R, Büchler MW, Friess H. Molecular Cancer. 2003; 2:14-14. [PubMed: 12605717]

85. Osinsky, SP., Ganusevich, II., Bubnovskaya, LN., Valkovskaya, NV., Kovelskaya, AV., Sergienko, TK., Zimina, SV. Exp Oncol. Vol. 27. Ukraine: 2005. p. 202-205.

86. Zhu L, Kate P, Torchilin VP. ACS Nano. 2012; 6:3491-3498. [PubMed: 22409425]

87. Terada, T., Iwai, M., Kawakami, S., Yamashita, F., Hashida, M. J Control Release. Vol. 111. Netherlands: 2006. p. 333-342.

88. Elegbede AI, Banerjee J, Hanson AJ, Tobwala S, Ganguli B, Wang R, Lu X, Srivastava DK, Mallik S. J Am Chem Soc. 2008; 130:10633-10642. [PubMed: 18642903]

89. Sarkar N, Banerjee J, Hanson AJ, Elegbede AI, Rosendahl T, Krueger AB, Banerjee AL, Tobwala S, Wang R, Lu X, Mallik S, Srivastava DK. Bioconjug Chem. 2008; 19:57-64. [PubMed: 18078309]

90. Sarkar NR, Rosendahl T, Krueger AB, Banerjee AL, Benton K, Mallik S, Srivastava DK. Chem Commun (Camb). 2005; :999-1001.doi: 10.1039/b416827e [PubMed: 15719095]

91. Banerjee J, Hanson AJ, Gadam B, Elegbede AI, Tobwala S, Ganguly B, Wagh AV, Muhonen WW, Law B, Shabb JB, Srivastava DK, Mallik S. Bioconjug Chem. 2009; 20:1332-1339. [PubMed: 19601658]

92. Liu, S., Bugge, TH., Leppla, SH. J Biol Chem. Vol. 276. United States: 2001. p. 17976-17984.

93. Duffy MJ. Biochem Soc Trans. 2002; 30:207-210. [PubMed: 12023852]

94. Basel MT, Shrestha TB, Troyer DL, Bossmann SH. ACS Nano. 2011; 5:2162-2175. [PubMed: 21314184]

95. Doring G. Am J Respir Crit Care Med. 1994; 150:S114-117. [PubMed: 7952645]

96. Al-Haik N, Lewis DA, Struthers G. Agents Actions. 1984; 15:436-442. [PubMed: 6098175]

97. Kawabata, K., Hagio, T., Matsuoka, S. Eur J Pharmacol. Vol. 451. Elsevier Science B.V.; Netherlands: 2002. p. 1-10.2002

98. Cantin AM, Hartl D, Konstan MW, Chmiel JF. J Cyst Fibros. 2015; doi: 10.1016/j.jcf.2015.03.003

99. Sato, T., Takahashi, S., Mizumoto, T., Harao, M., Akizuki, M., Takasugi, M., Fukutomi, T., Yamashita, J. Surg Oncol. Vol. 15. Netherlands: 2006. p. 217-222.

100. Moroy, G., Alix, AJ., Sapi, J., Hornebeck, W., Bourguet, E. Anticancer Agents Med Chem. Vol. 12. Netherlands: 2012. p. 565-579.

101. Yamashita J, Ogawa M, Shirakusa T. J Leukoc Biol. 1995; 57:375-378. [PubMed: 7884307]

102. Starcher, B., O’Neal, P., Granstein, RD., Beissert, S. J Invest Dermatol. Vol. 107. United States: 1996. p. 159-163.

103. Pak CC, Ali S, Janoff AS, Meers P. Biochimica et Biophysica Acta (BBA) - Biomembranes. 1998; 1372:13-27. [PubMed: 9651469]

104. Pak CC, Erukulla RK, Ahl PL, Janoff AS, Meers P. Biochimica et Biophysica Acta (BBA) Biomembranes. 1999; 1419:111-126. [PubMed: 10407064]

105. Denmeade SR, Sokoll LJ, Chan DW, Khan SR, Isaacs JT. Prostate. 2001; 48:1-6. [PubMed: 11391681]

106. Basu HS, Frydman B. Expert Opinion on Therapeutic Patents. 2002; 12:1035-1046.

107. Chandran, SS., Nan, A., Rosen, DM., Ghandehari, H., Denmeade, SR. Mol Cancer Ther. Vol. 6. United States: 2007. p. 2928-2937.

108. Denmeade SR, Jakobsen CM, Janssen S, Khan SR, Garrett ES, Lilja H, Christensen SB, Isaacs JT. J Natl Cancer Inst. 2003; 95:990-1000. [PubMed: 12837835]

109. Denmeade SR, Nagy A, Gao J, Lilja H, Schally AV, Isaacs JT. Cancer Res. 1998; 58:2537-2540. [PubMed: 9635575]

110. Khan, SR., Denmeade, SR. Prostate. Vol. 45. Wiley-Liss, Inc; United States: 2000. p. 80-83.2000

111. Xiang B, Dong DW, Shi NQ, Gao W, Yang ZZ, Cui Y, Cao DY, Qi XR. Biomaterials. 2013; 34:6976-6991. [PubMed: 23777916] 
112. Wender PA, Mitchell DJ, Pattabiraman K, Pelkey ET, Steinman L, Rothbard JB. Proceedings of the National Academy of Sciences of the United States of America. 2000; 97:13003-13008. [PubMed: 11087855]

113. Perner, S., Hofer, MD., Kim, R., Shah, RB., Li, H., Moller, P., Hautmann, RE., Gschwend, JE., Kuefer, R., Rubin, MA. Hum Pathol. Vol. 38. United States: 2007. p. 696-701.

114. Gondi CS, Rao JS. Expert Opin Ther Targets. 2013; 17:281-291. [PubMed: 23293836]

115. Hafez, IM., Cullis, PR. Adv Drug Deliv Rev. Vol. 47. Netherlands: 2001. p. 139-148.

116. Romberg, B., Flesch, FM., Hennink, WE., Storm, G. Int J Pharm. Vol. 355. Netherlands: 2008. p. 108-113.

117. Metselaar JM, Bruin P, de Boer LW, de Vringer T, Snel C, Oussoren C, Wauben MH, Crommelin DJ, Storm G, Hennink WE. Bioconjug Chem. 2003; 14:1156-1164. [PubMed: 14624629]

118. Liu X, Huang G. Asian Journal of Pharmaceutical Sciences. 2013; 8:319-328.

119. Ellens H, Bentz J, Szoka FC. Biochemistry. 1984; 23:1532-1538. [PubMed: 6722105]

120. Simoes, S., Moreira, JN., Fonseca, C., Duzgunes, N., de Lima, MC. Adv Drug Deliv Rev. Vol. 56. Netherlands: 2004. p. 947-965.

121. Zhang, JX., Zalipsky, S., Mullah, N., Pechar, M., Allen, TM. Pharmacol Res. Vol. 49. England: 2004. p. 185-198.

122. Kirpotin, D., Hong, K., Mullah, N., Papahadjopoulos, D., Zalipsky, S. FEBS Lett. Vol. 388. Netherlands: 1996. p. 115-118.

123. Ishida T, Kirchmeier MJ, Moase EH, Zalipsky S, Allen TM. Biochim Biophys Acta. 2001; 1515:144-158. [PubMed: 11718670]

124. Mura S, Nicolas J, Couvreur P. Nat Mater. 2013; 12:991-1003. [PubMed: 24150417] 


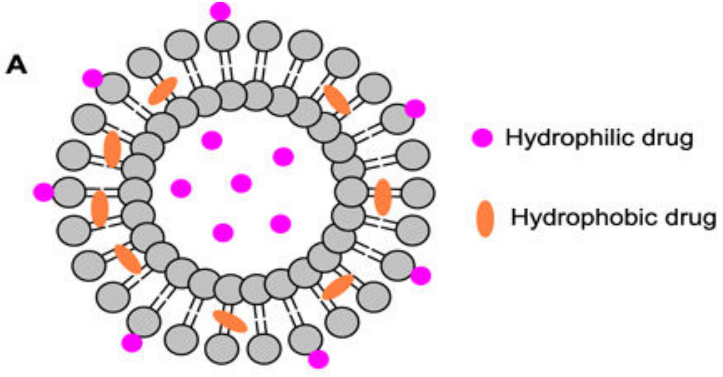

B.<smiles>CCCCCCCCCCCCCCCCCCCCCCC(=O)OC[C@H](COP(=O)(O)OCC[N+](C)(C)C)OC(=O)CCCCCCCCCCCCC</smiles>

C.<smiles>CCCCCCCCCCCCCCCCCCCCCCCCCC(=O)OC[C@H](COP(=O)([O-])OCC[NH3+])OC(=O)CCCCCCCCCC</smiles>

Figure 1.

Schematic representation of a drug-loaded liposome, and structure of two common phospholipids. (A) Hydrophilic drugs are encapsulated in the liposomal core or conjugated to the surface and the hydrophobic drugs partition into the lipid bilayer. (B) 1,2-distearyl-snglycero-3-phosphocholine (DSPC), (C) 1,2-distearyl-sn-glycero-3-phosphoethanolamine (DSPE). 
A. Phosphatidylethanolamine<smiles>[R]C(=O)OC[C@H](COP(=O)([O-])OCC[NH3+])OC([R])=O</smiles>

C. Phosphatidylglycerol

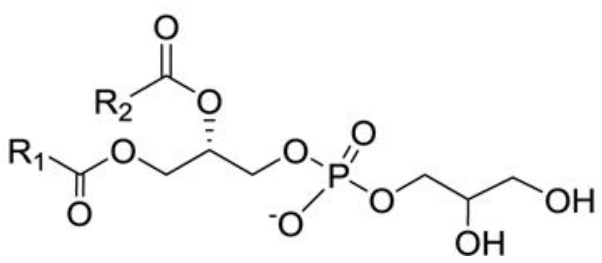

B. Phosphatidylcholine<smiles>[R]C(=O)OC[C@H](COP(=O)([O-])OCC[N+](C)(C)C)OC([R])=O</smiles>

D. Phosphatidylserine<smiles>[R]C(=O)OC[C@H](COP(=O)([O-])OC[C@H]([NH3+])C(=O)O)OC([R])=O</smiles>

Figure 2.

(A) Neutral phospholipid and (B) anionic phospholipids. 
A.

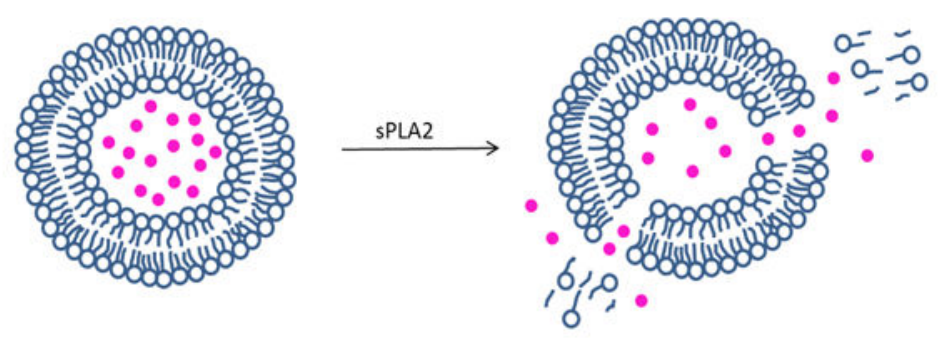

- Encapsulated drug

L Lysophospholipid

I Fatty acid<smiles>CCCCCCCCCCCCCCCCCCCCCCCCCCCCC(=O)OCC(COP(=O)([O-])OCC[NH3+])OC(=O)CCCCCCC</smiles>

1,2-distearyl-sn-glycero-3-phosphoethanolamine (DSPE)

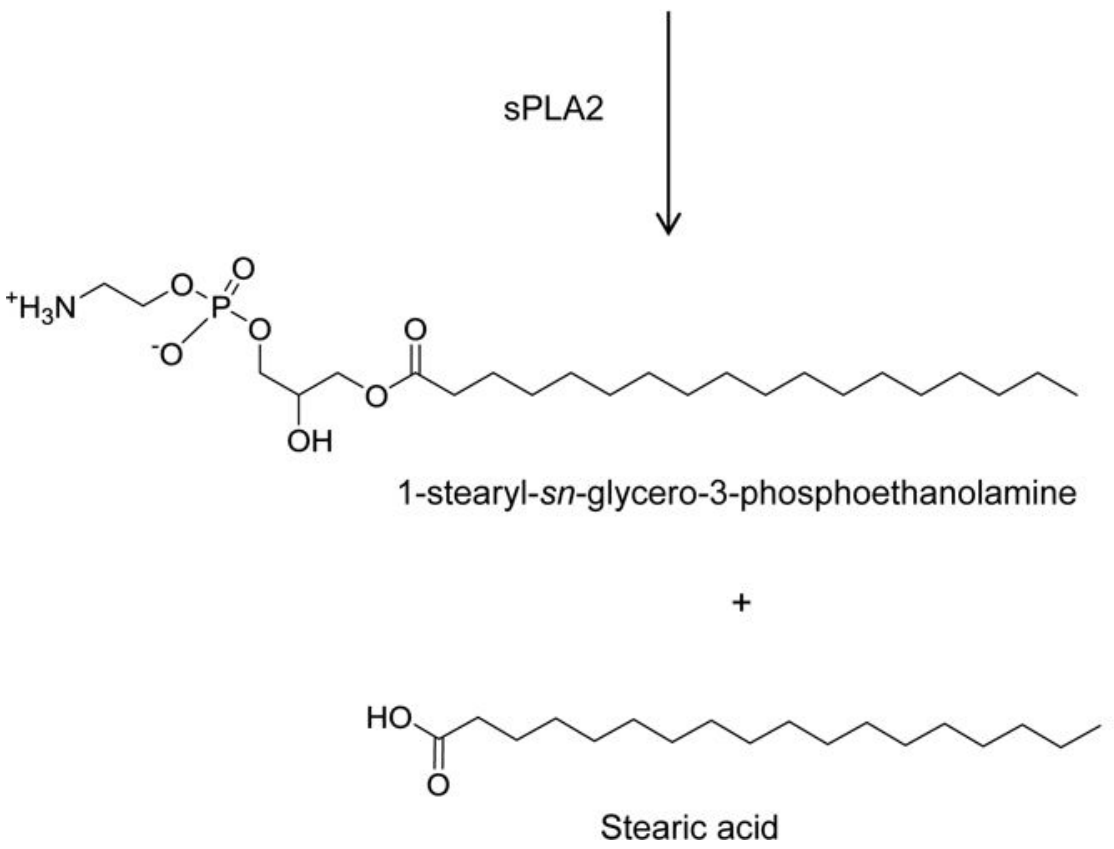

Figure 3.

(A) Drug release from sPLA 2 sensitive liposomes, and (B) sPLA $_{2}$ mediated hydrolysis of DSPE. 
<smiles>CCCCCCCCc1ccc(-c2ccc(C(=O)OCCCCCC(=O)O[C@H](COC[C@@H](O)CO)COP(=O)([O-])OC[C@H](O)CO)cc2)cc1</smiles>

B.<smiles>CCCCCCCCCCCCCCCCCCOC[C@H](COP(=O)([O-])OC[C@H](O)CO)OC(=O)CCCc1ccc(N(CCCl)CCCl)cc1</smiles>

C.<smiles>CCCCCCCCCCCCCCCCCCOC[C@H](COP(=O)([O-])OC[C@H](O)CO)OC(=O)CCCC/C=C/C=C1\C(=O)C=CC1CCC</smiles>

Figure 4.

(A) C6-RAR prodrug, (B) chlorambucil prodrug, and (C) 15-deoxy- $\Delta 12,14$ prostaglandin J2 prodrug. sPLA 2 hydrolyzable bond is shown by an arrow. 


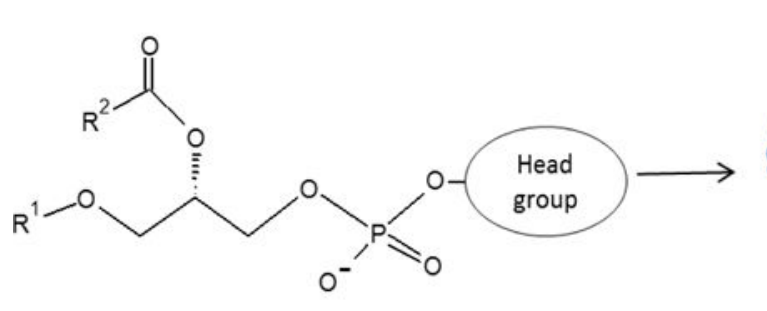

PrOAEL
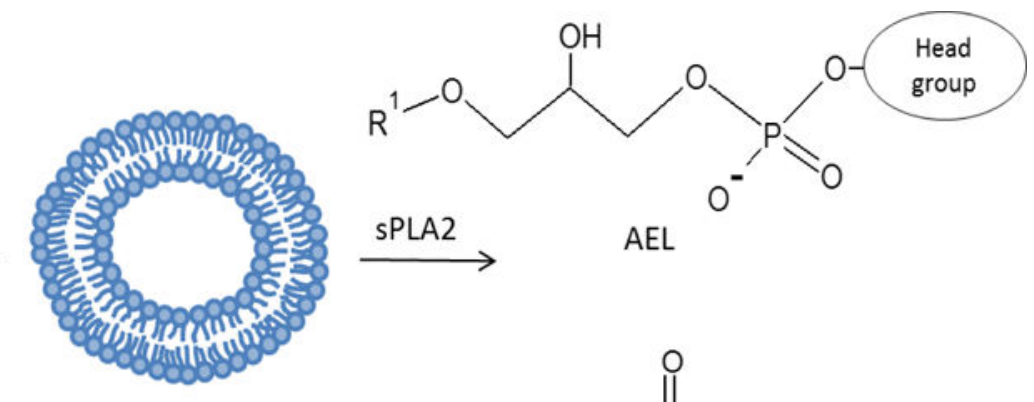

Prodrug

liposome

AEL

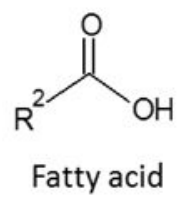

Figure 5.

Schematic structure of ProAELs which form liposomes. sPLA 2 -mediated hydrolysis of ProAEL releases AEL and fatty acid in the tumor tissue. 


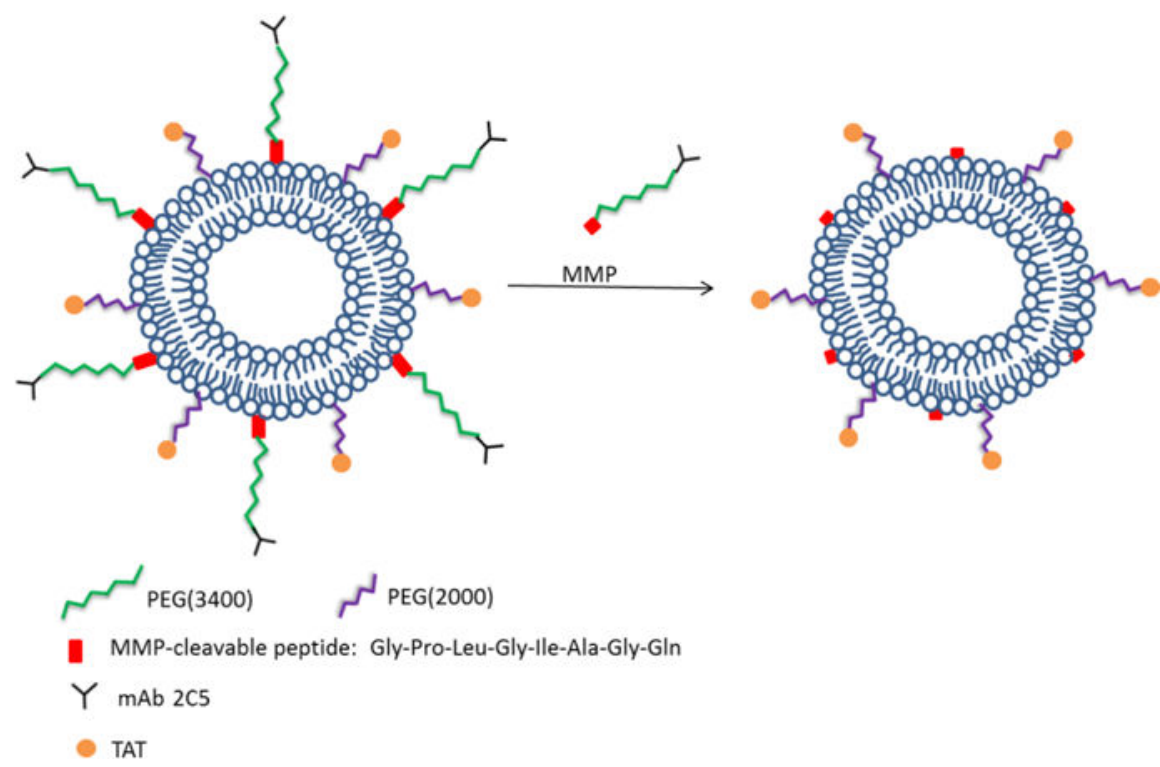

Figure 6.

MMP-responsive liposomes. The MMP-cleavable peptide is hydrolyzed between Gly and Ile. Cleavage of this peptide removes the long PEG chain from the surface of liposomes and exposes the targeting ligand. 

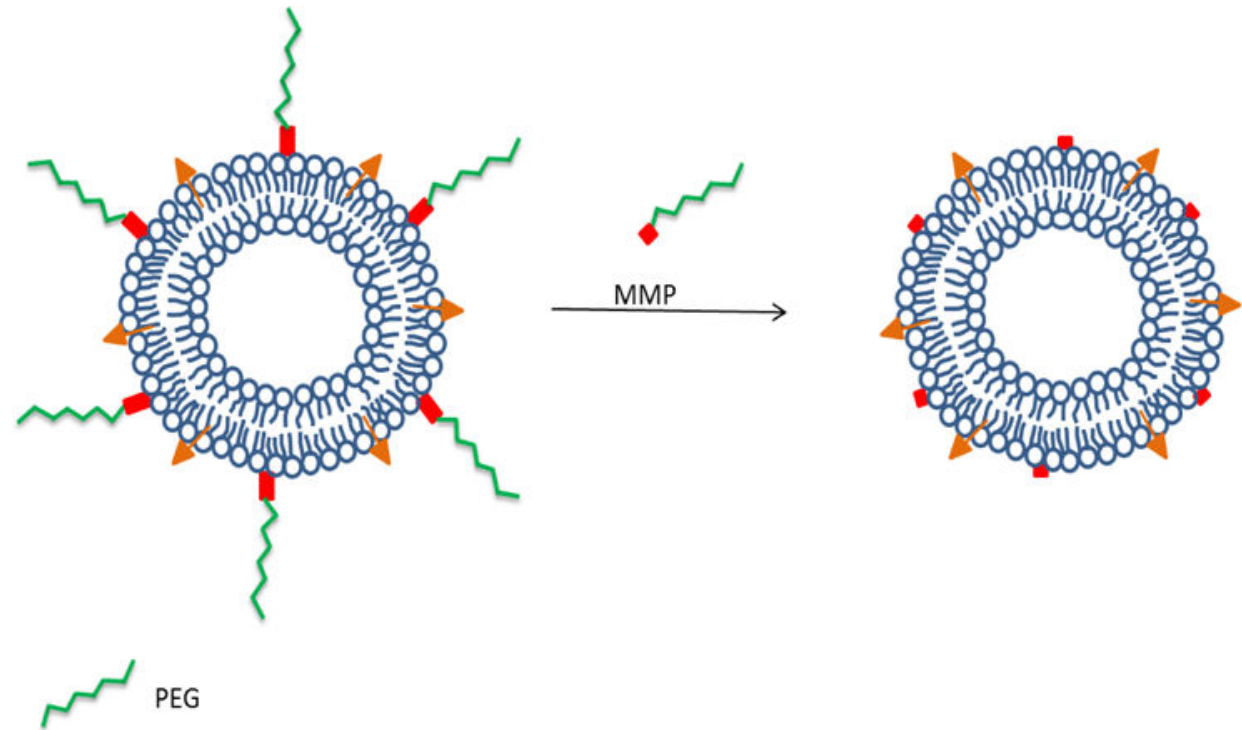

MMP-cleavable peptide: Gly-Pro-Leu-Gly-Ile-Ala-Gly-GIn

Galactosylated cholesterol derivative:

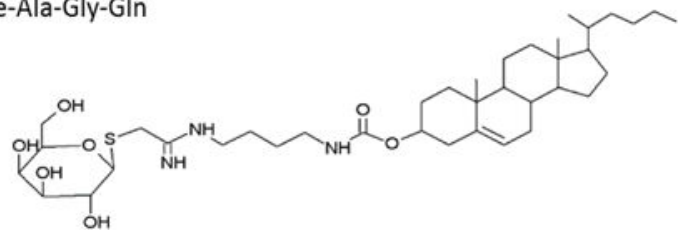

Figure 7.

MMP-responsive liposomes targeted to hepatocellular carcinoma (HCC). In the tumor tissue, a high concentration of MMP-2 cleaves the linker and removes PEG from the surface of the liposome. This results in the exposure of galactose on the surface and subsequent uptake of liposomes by HCC cells. 

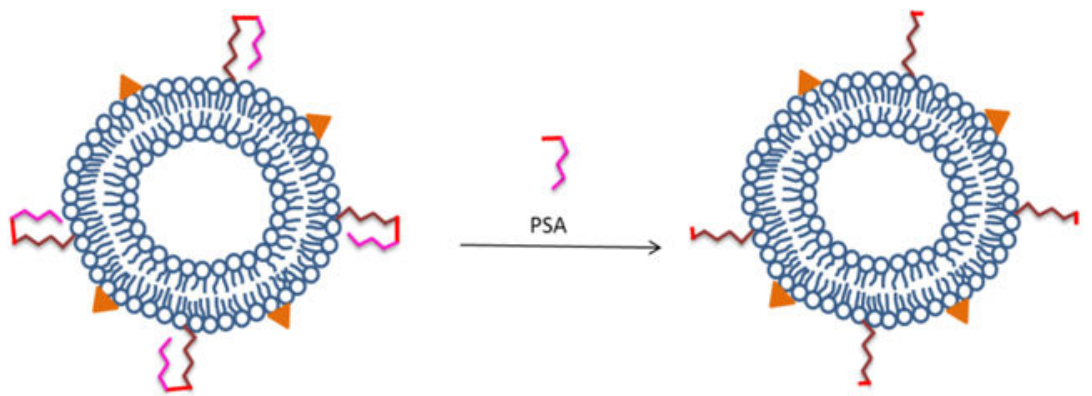

$$
\begin{aligned}
& \text { Cell penetrating peptide ( } \left.\mathrm{GR}_{\mathrm{g}} \mathrm{GC}\right) \\
& \text { PSA-cleavable peptide (HSSKYQ) } \\
& \sum \text { Polyanionic peptide (DGGDGGDGGDGG) } \\
& \nabla \text { Folate }
\end{aligned}
$$

Figure 8.

PSA responsive liposomes. The liposomes are decorated by a peptide with three domains (cell penetrating, PSA-cleavable, and polyanionic) and a targeting ligand (folate). Cleavage of the peptide by PSA liberates the polyanionic domain and activates cell penetrating peptide, leading to increased uptake of the liposomes by prostate cancer cells. 
A.

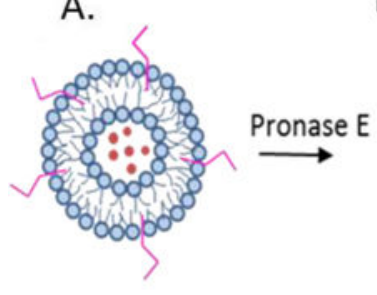

B.

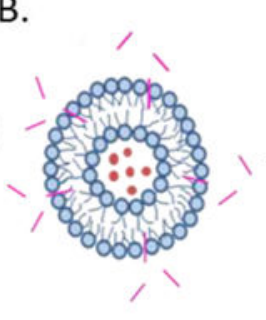

c.
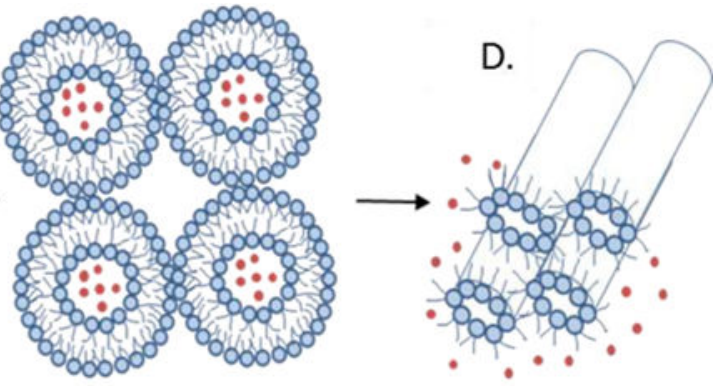

DODASUC-PHEG

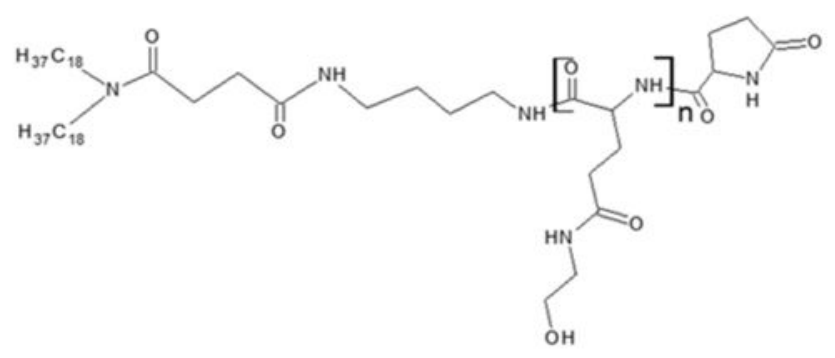

DOPE

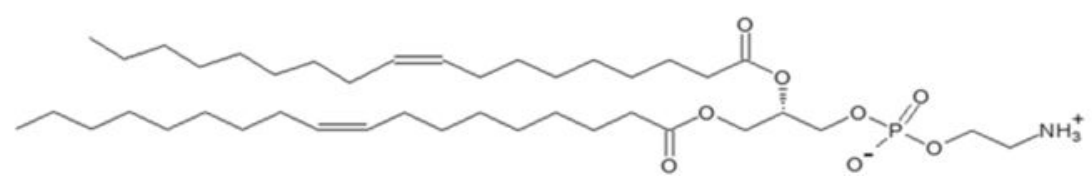

Figure 9.

Fusogenic liposomes stabilized by DODASuc-PHEG (A). In the presence of pronase E, the polyamino acid is degraded (B), leading to the destabilization and fusion of liposomes $(\mathbf{C})$. Conversion of liposomes from the lipid bilayer phase to the inverted hexagonal $\mathrm{H}_{\text {II }}$ phase releases the encapsulated contents (adapted from Romberg B et al., 2008 ${ }^{116}$ ). 